\title{
INFLUENCE OF CLIMATE FACTORS ON YIELD AND QUALITY OF SOME VINE CULTIVARS FROM THE ȘTEFĂNEȘTI CENTER
}

\author{
A. Badulescu ${ }^{1 *}$, D.I. Sumedrea ${ }^{1}$, A. Florea ${ }^{1}$, A. Onache $^{1}$ and \\ A. Tanase $^{1}$
}

1National Research and Development Institute for Biotechnology in Horticulture Ștefănești - Arges, no. 37 Bucharest - Pitești Street, Argeș County, 117715, România

\footnotetext{
* Corresponding author email: badulescuadriana18@yahoo.com
}

\begin{abstract}
The influence of climatic factors on grape yield, fertility indicators of grapes (absolute coefficient of fertility, relative coefficient of fertility, absolute productivity indices, relative productivity indices), but also sugar and total acidity content in three cultivars of 'Fetească' ('Fetească Albă', 'Fetească Neagră' and 'Fetească Regală', respectively) was evaluated during 2016-2020 2016 period at the experimental field of National Research and Development Institute for Biotechnology in Horticulture Ștefănești. The highest grape yield were recorded in 2018 to all three Cultivars analysed (20,33 t/ha 'Fetească Albă', 19,44 t/ha 'Fetească Neagră' and 19t/ha 'Fetească Regală', respectively), while the lowest values were measured in 2016 at all cultivars. Highest sugar content was measured in 2019 and 2020, and lowest in 2017, 2016, respectively. The highest acid content was recorded in 2017 and $2016(4,64$ $\mathrm{g} / \mathrm{l}, 4,65 \mathrm{~g} / \mathrm{l}$, respectively) as a result of heavy rainfall during the growing season, especially in June and September. Differences between the studied parameters were statistically significant. The results of the five years showed that the yield and quality of grapes were in direct relation with the weather conditions in certain years of experiments.
\end{abstract}

Keywords: Feteasca cultivars, climatic factors, yield, quality of grapes, coefficient of fertility

\section{INTRODUCTION}

Romania's viticulture is recognized for vineyards and viticultural centres, known notonly for their fine wines, but also for the special quality of table grapes. The complexityof Romanian geographic landscape creates favourable ecoclimates for the cultivation of table grapes cultivars, known for being more demanding than heliothermic and hydricregimes. An increasing temperature was reported in Europe by many scientists, e.g. Guedon and Legave (2008) by about $1.1-1.3^{\circ} \mathrm{C}$ in France, Blanke and Kunz (2017) by $0.6^{\circ} \mathrm{C}$ and Waldauand Chmielewski (2018) by $1.9^{\circ} \mathrm{C}$, the last two in various regions of Germany. Due to climate change with warmer winters and earlier springs, temperate fruit crop adaptation in many places will be at risk in the future (Wenden et al., 2017). In Romania, data on climate for the investigated region were first reported about two decades ago (Paltineanu et al., 2000), and the trend of warming has been noted by Paltineanu et al. (2012). More recently, Busuioc et al. (2015) reportedan increasing trend in air temperature during the 1962-2010 period in Romania, while Chitu et al. (2015), Florea et. al (2020) emphasized the increased variability of seasonal and annual extreme temperature trends of the latest three decades in the study 
region. Moreover, the current climate warming favours this direction of production. Statistical data from 2018 show that the total area cultivated with vine for wine in Romania was 171.2 ha in 2016, 170.3 in 2017 and 171.1 ha in 2018 and the total wine production was 33030. 7 thousand hl in 2016, 4264.1 in 2017 and, respectively 5088.1 in 2018. (Ministry of Agriculture and Rural Development, Data source: point 1.2 - INS date - Online tempo, point 1.3 - MADR operative date, point 4). 'Feteasca Albă'cultivar is cultivated in 2018 on an area of 9,298 ha, 'Feteasca Regala' 14,010 ha and only 2950 ha are cultivated with 'Feteasca Neagră' (Ministry of Agriculture and Rural Development, Data SourceNational Institute of Statistics). The total area under table grape cultivars is 8.993 ha and the total production is about 124.400 tones of grapes for fresh consumption (National Office of Vine and Wine Products -ONVPV, 2017). Numerous studies worldwide predict that extreme future weather conditions will be more frequent, and negative impact on agricultural productionwill be more noticeable. However, it should always be considered that in addition to agro ecological conditions (relief, exposure, temperature sums, radiation, physical and mineral properties of soil), agrobiological, economical and technological properties of grape vines are significantly affected by the level of applied ampelotechnics, the type of rootstock, growth form, the pruning technique and many others (Brighenti et al., 2010). All listed above impose a constant need for research ofimpact of changing climate on agrotechnological and economical characteristics of the dominantly cultivated cultivars of vine in south of Romania, and therefore the cultivars'Feteasca'as well, which was one of the leading vine cultivars for the production of high quality wines. The aim of this study is to evaluate the impact of major climatic parameters on the yield and quality of grape of three cultivars of 'Feteasca', especially during the vegetation season in Ștefănești wine growing region in the last 5 years.

\section{MATERIALS AND METHODS}

The study of the influence of climatic factors on the yield and quality atthree cultivars of grapes of wine 'Feteasca Albă', 'Feteasca Neagră' and 'Feteasca Regală' was conducted in 2016, 2017, 2018, 2019 and 2020, respectively. The study was performed at the experimental field of the National Research and Development Institute for Biotechnology in Horticulture, Ștefănești. Experimental vineyard was planted in 2004 with the planting distance of $2.50 \mathrm{~m}$ between rows and $1 \mathrm{~m}$ within rows. Growing form of vine is double horizontal cordon with trunk height of about $80 \mathrm{~cm}$. Mixed pruning was applied. The set of quantitative and qualitative characteristics was basic in due following indicators: relative coefficient of fertility, absolute coefficient of fertility, relative productivity indices, absolute productivity indices and production, total tritrable acidity (TTA), total sugar content (TSC). Fertility and productivity are biological characteristics, describing agrobiological and technological value of grape cultivars. To calculate the fertility, it was necessary to register buds number on block, total number of shoots, total fertile shoots and inflorescences number. Fertility coefficient was calculated as absolute (Afc) and relative (Rfc). Therefore, $A f c=$ Number of inflorescences/Number of fertil shoots, and Rfc $=$ Number of inflorescences/ Number of total shoots, respectively. The productivity was calculated through absolut productivity indices (Ipa) and relative productivity indices (Ipr),using the following formulas: Ipa $=$ Afc $\times \mathrm{Gm}$, Ipr $=$ Rcf $\times \mathrm{Gm}$, with Afc - absolute fertility coefficient; Rfc - relative fertility coefficient and $\mathrm{Gm}$ - average grape weight. The total acidity was determined by the titrimetric method. The total sugars contentwere evaluated by refractometric method, by measuring the percentage of soluble solidsor refractive index, after prior removal ofalcohol and volatile compounds from wine (which changes the refractive index value). For the statistical interpretation of the results, the data were 
included in an Excel database and then statistically interpreted with the SPSS 14.0 program, which uses the Duncan test (multiple range test) for a 5\% statistical assurance.

\section{RESULTS AND DISCUSSIONS}

Yield quantity and quality is heavily influenced by climate and the prevailing meteorological conditions in production regions (Mirošević and Karoglan - Kontić, 2008). Air temperature exerts dominant influence on vines depending on vine phenological dynamics, and in current climate changing condition, heat regime changes are the most pronounced. We had available for this analysis, daily climatological databases collected from the meteorological platform of the National Research and Development Institute for Biotechnologies in Horticulture, Ștefănești, for the experimental period (2016-2020), ascompared to multiannual values (1977-2014).

Monthly average temperatures were used to calculate a set of bioclimatic indices commonlyused in viticulture. During the study period (2016-2020), higher temperatures were recorded, as compared to the multiannual average, especially with regard to the maximum annual temperatures (Table 1). At the same time, the absolute minimum winter temperatures have been harmful to the vine in all the three years of experimentation.

Table 1. The climatic indicators during experimentation period (2016-2020) compared to the multianual average (1979-2015), at INCDBH Ștefănești

\begin{tabular}{|l|c|c|c|c|c|c|}
\hline Climatic indicator & $\begin{array}{c}\text { Multianual } \\
\text { average } \\
(1979-2015)\end{array}$ & 2016 & 2017 & 2018 & 2019 & 2020 \\
\hline Average annual temperature, ${ }^{0} \mathrm{C}$ & 10.68 & 12.08 & 11.94 & 12.09 & 12.81 & 12.23 \\
\hline $\begin{array}{l}\text { Average temperature in the growing season, } \\
{ }^{0} \mathrm{C}(\mathrm{IV}-\mathrm{X})\end{array}$ & 16.66 & 14.74 & 15.06 & 19.21 & 18.37 & 19.93 \\
\hline Average temperature in summer, ${ }^{0} \mathrm{C}(\mathrm{VI}-\mathrm{VIII})$ & 20.77 & 23.2 & 23.13 & 22.27 & 22.87 & 19.35 \\
\hline Average annual minimum temperature, ${ }^{\circ} \mathrm{C}$ & 6.13 & 5.8 & 5.42 & 6.09 & 6.23 & 7.8 \\
\hline Absolute minimum temperature, ${ }^{\circ} \mathrm{C}$ & -22.4 & -16.6 & -9.6 & -18.4 & -16.6 & -10.9 \\
\hline Average January minimum temperature, ${ }^{0} \mathrm{C}$ & -3.88 & -6.2 & -9.4 & -10.7 & -12.7 & -10.1 \\
\hline Average annual maximum temperature, ${ }^{0} \mathrm{C}$ & 21.74 & 20.81 & 20.99 & 21.09 & 21.82 & 23.72 \\
\hline Average July maximum temperature ${ }^{0} \mathrm{C}$ & 28.1 & 34.8 & 33.1 & 32.4 & 32.5 & 37.7 \\
\hline Annual total precipitation, mm & 725.08 & 858.2 & 843.4 & 831.2 & 657.6 & 380 \\
\hline $\begin{array}{l}\text { Total precipitation in the growing season, } \\
\text { mm (IV-X), }\end{array}$ & 494.33 & 606.4 & 631.2 & 480 & 444.2 & 337 \\
\hline The total precipitation in summer (VI-IX) & 304.7 & 338.6 & 330.4 & 303.8 & 258.4 & 225.4 \\
\hline
\end{tabular}

The vegetation periods of 2016 and 2020 were drier and summer rainfall (VI-IX) was lower than usual except for 2016 and 2017, when the precipitation exceeded the normal values by $33.9 \mathrm{~mm}, 45.7$ respectively. These climatic conditions have led to changes in the development of the grapes' yield and its quality. Table1 describes the climatic indicators during the experimentation period (2016-2020) compared to the multianual average (19792015), at INCDBH Ștefănești. Table 1 clearly shows that air temperature in Ștefănești vine growing region is in constant growth, especially in the summer period. With climate anomalies, expressed through the differences in the values of climate parameters between the multi-year average (1979-2015) and the period from 2016 to 2020, highlighted that the climate in this wine-growing region is rapidly changing. Compared to long-term averages, average annual air temperature was higher with $1.4^{\circ} \mathrm{C}$ in 2016 was higher in $2017-1.26^{\circ} \mathrm{C}$, with $1.41^{\circ} \mathrm{C}$ in 2018 , in 2019 with $2.13^{\circ} \mathrm{C}$, and in 2020 was with higher that $1.55^{\circ} \mathrm{C}$ at the level of long-term averages.

Applying the strongest statistical test in order to verify the normality of the distribution (Shapiro-Wilk, W), the values $\mathrm{W}=0.942$ at Afc, $\mathrm{W}=0.967 \mathrm{Rfc}, \mathrm{W}=0.688 \mathrm{Ipc}$ and 
$\mathrm{W}=0.887$ Ipr were obtained which determines the acceptance of normality in the case of all quantitative indicators analysed (table 2). Grape yield per area unit, as an absolute indicator of productivity of cultivars, is conditioned by a number of factors. Among the more important are biological characteristic of the cultivar and environmental conditions in the studied years. The results of histograms of quantitative indicators showed that the yield of grapes was in accordance with the weather conditions.

Table 2. Statistical tests from verification the normality of the distribution of biological indicators in Fetească Albă, Fetească Neagră and Fetească Regală cultivars

\begin{tabular}{|c|c|c|c|c|c|c|}
\hline \multirow[b]{2}{*}{ Indicators } & \multicolumn{3}{|c|}{ Kolmogorov-Smirnov(a) } & \multicolumn{3}{|c|}{ Shapiro-Wilk } \\
\hline & Statistic & $\mathrm{df}$ & Sig. & Statistic & $\mathrm{df}$ & Sig. \\
\hline $\begin{array}{l}\text { Absolute coefficient of fertility } \\
\text { (a.f.c) }\end{array}$ & .119 & 180 & .000 & .942 & 180 & .000 \\
\hline Relative coefficient of fertility & .144 & 180 & .000 & .967 & 180 & .000 \\
\hline $\begin{array}{l}\text { Absolute productivity indices } \\
\text { (bunches/shoot) }\end{array}$ & .328 & 180 & .000 & .688 & 180 & .000 \\
\hline Relative productivity indices & .187 & 180 & .000 & .887 & 180 & .000 \\
\hline Productions (t/ha) & .110 & 180 & .000 & .942 & 180 & .000 \\
\hline
\end{tabular}

a Lilliefors Significance Correction

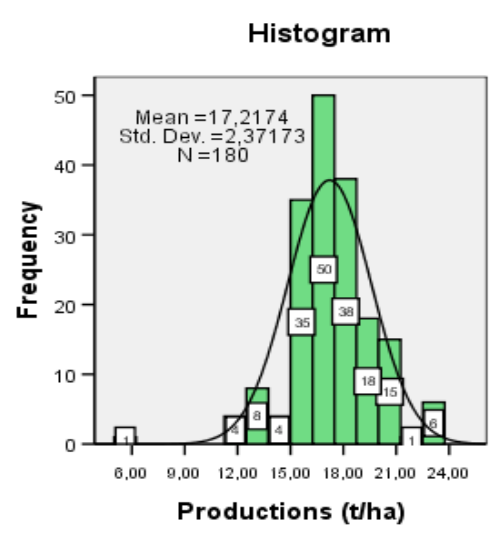

Figure 1. Histogram of class distribution of absolute frequency of the production

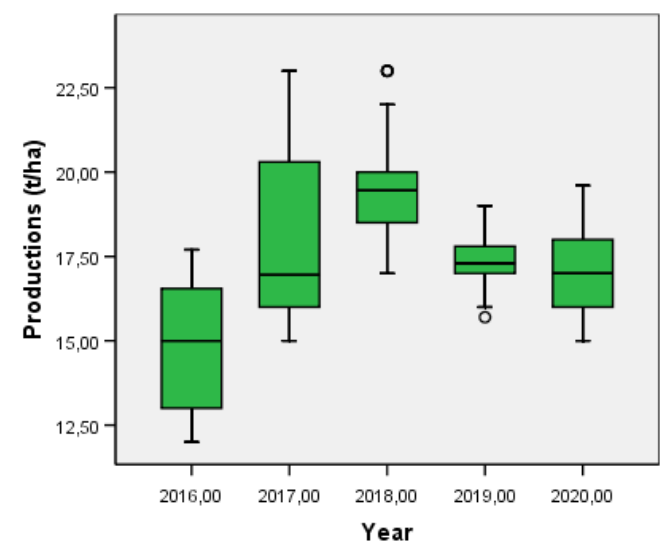

Figure 2. The box plot describes the distribution of yield (tons per hectars) related to the three cultivars 


\section{Relative productivity indices}

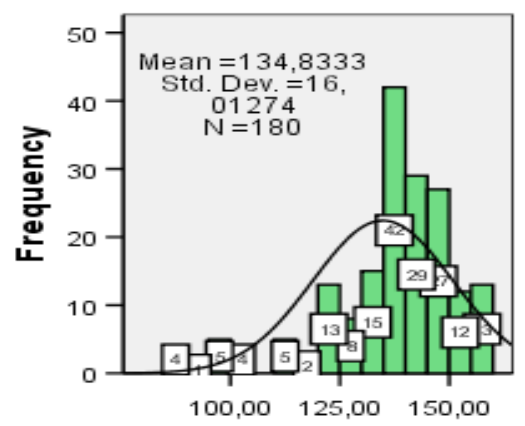

Figure 3. Histogram of class distribution of absolute frequency of the relative productivity index

\section{Absolute coefficient of fertility (a.f.c)}

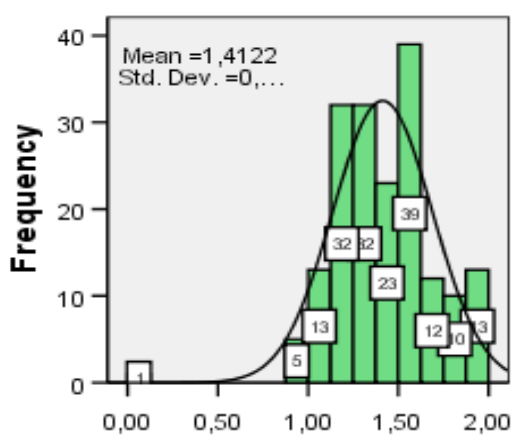

Figure 5. Histogram of class distribution of absolute frequency of the absolute coefficient of fertility

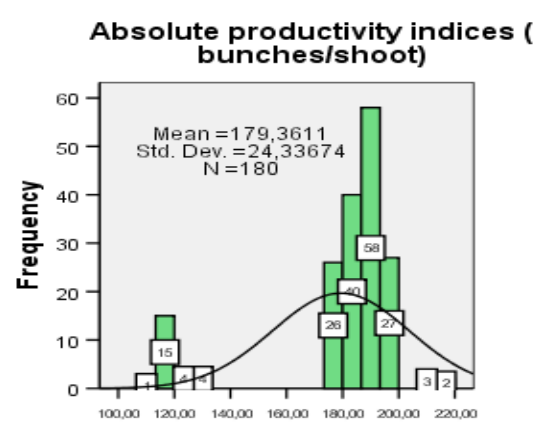

Figure 4. Histogram of class distribution of absolute frequency of the absolute productivity indices

\section{Relative coefficient of fertility}

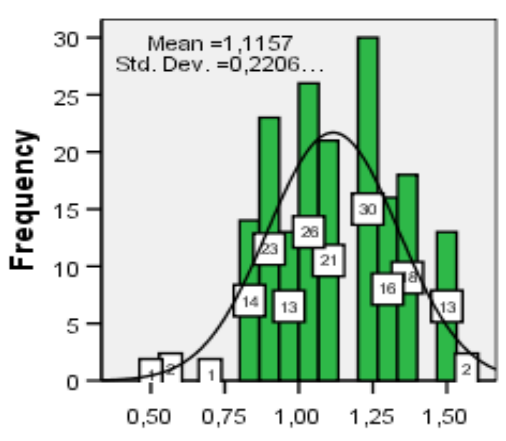

Figure 6. Histogram of class distribution of absolute frequency of the relative coefficienty of fertility

To was determine the grape production the of analysis the between the interaction cultivar andyear of study the Duncan test used (figures 7 and 8). The analysis of the influence of the cultivars on the production ofgrapes, depending on the years analysed, we but into evidence the following results (figure 8):

- Talking into account the average of grape production during the five years of study.

- On the average of the 5 years of study, the largest grape production was recorded in the cultivars 'Fetească Albă' (17.66 t/ha), followed by 'Fetească Neagră', and the lowest production was recorded in the cultivars 'Feteasca Regala' $(16.84, \mathrm{t} / \mathrm{ha})$, the differences between them not being statistically ensured (figure 8).

- The highest values of grape production were registered in 2018 (19.59 t/ha), followed by 2017 (17.34t /ha), and the lowest values of this indicator in 2016 (14.71t/ha). 


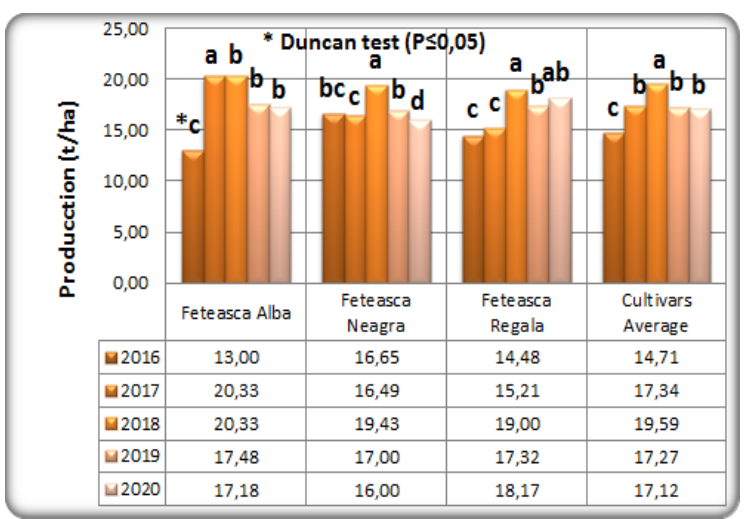

Figure 7. Influence of the production of grapes, depending on the cultivars

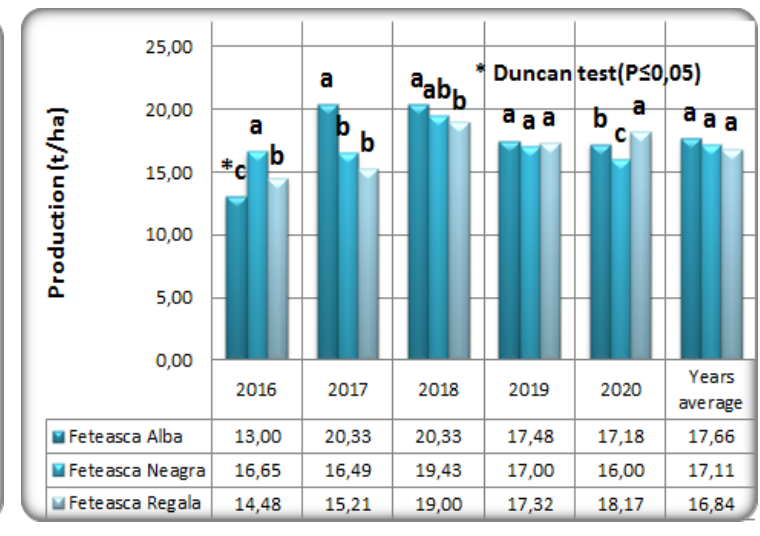

Figure 8. Influence of the cultivar on the production, depending on the years

Wine grape cultivars are usually harvested at a high sugar content, compared to table grapes. According to The International Organisation of Vine and Wine (OIV), resolution VITI 1/2008, grapes with a Brix degree equal to, or above 16 , shall be considered ripped (OIV, 2008).Therefore, to determine the qualitative indicators of grape the interaction between of cultivarandyear of study using the Duncan test (figures 9, 10, 11 and 12).

Based on the results shown in figures 9, was performed the highest sugar content of the grapes was measured in $2020(228,78 \mathrm{~g} / \mathrm{l})$ followed by 2019 year, and the lowest in 2017 (196,68 g/l) and 2016, (197,0 g/l), respectively. This is the direct consequence of the variation in weather conditions that prevailed during the experiment period. In 2017 and 2016, with the lowest mean air temperature in vegetation period and the highest amount of precipitation in the vegetation period, the sugar content was lowest. Similar results were reported by Odăgeriu et al. (2012), Antoce (2018) who measured higher sugar content in years with higher mean temperatures in vegetation period. The importance and impact of growing conditions on the yield and quality of grapes indicate Mota et al. (2008).If we analyse the influence of the cultivars on the total sugar content of grapes, depending on the years analysed, we emphasize the following results (figure 10), on the average years, the highest content in total fruit sugar was obtained from the 'Feteasca Regala' (216,25 g/l) cultivar and the lowest values to the 'Feteasca Alba' cultivar $(209,64 \mathrm{~g} / \mathrm{l})$.

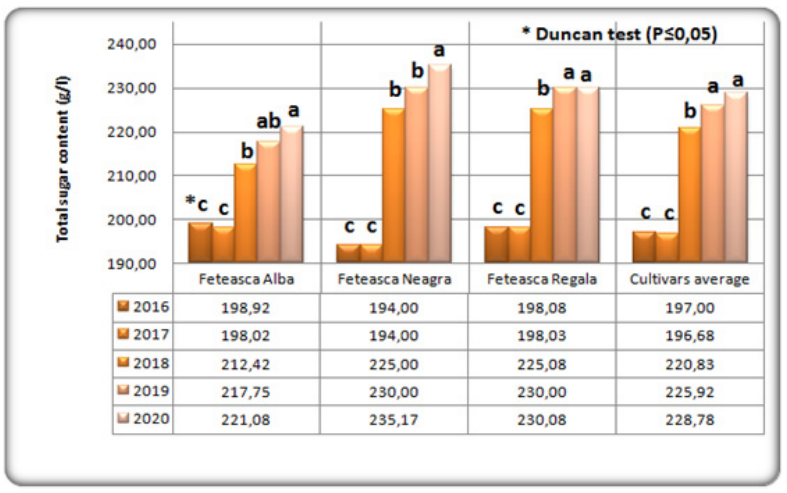

Figure 9. Influence of the total sugar content of grapes, depending on the cultivars

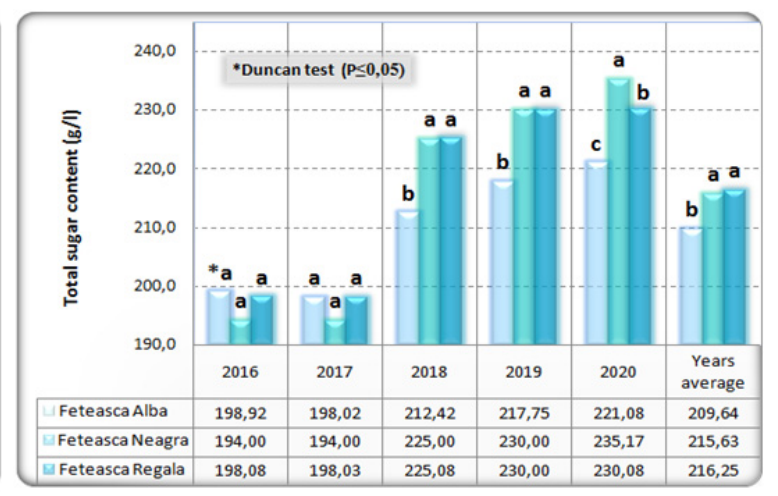

Figure 10. Influence of the cultivar on thetotal sugar content $(\mathrm{g} / \mathrm{l})$, depending on the years 


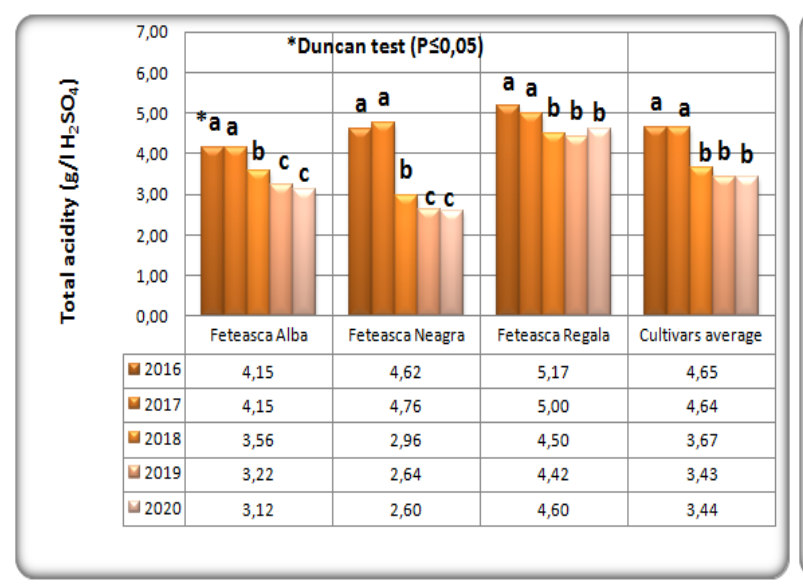

Figure 11. Influence of the total acidity of grapes, depending on the cultivars

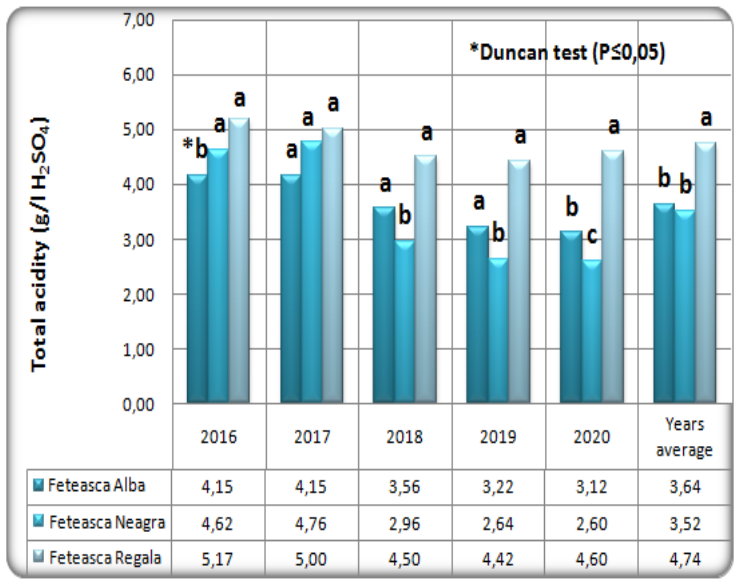

Figure 12. Influence of the cultivar on thetotal acidity (g/l), depending on the years

In these two years total rainfall in the growing season, mm (IV-X), exceeded normal (494.33 $\mathrm{mm}$ ) by $112.07 \mathrm{~mm}$ in 2016 and $136.87 \mathrm{~mm}$ in 2017. Average of the cultivars, the highest values of grape acidity were registered in $2016\left(4.65 \mathrm{~g} / \mathrm{l} \mathrm{H}_{2} \mathrm{SO}_{4}\right)$, followed by 2017 (4.64 $\left.\mathrm{g} / \mathrm{l} \mathrm{H}_{2} \mathrm{SO}_{4}\right)$, and the lowest values of this indicator in 2019 and $2020\left(3.43 \mathrm{~g} / \mathrm{l} \mathrm{H}_{2} \mathrm{SO}_{4}\right.$, $3.45 \mathrm{~g} / \mathrm{l} \mathrm{H}_{2} \mathrm{SO}_{4}$, respectively), the differences between them being statistically ensured (figure 11). The low content of grapes in acidity in 2019 and 2020 is due to their higher accumulations in total sugar. The development of grapes maturation in warmer times more than usual, has led to a forced and increased accumulation of sugars, an excessive reduction in acidity, which affects the balance between sugar and acids and requires a careful choice of the harvesting time. The best ratio between the total sugar content of grapes and acidity was registered in 'Feteasca Regala' cultivar. Similar results were reported by Antoce (2018) in five clones of 'Feteasca Neagra' cultivated in regions with higher mean temperatures during vegetation periodwho registered higher sugar content.

\section{CONCLUSIONS}

- $\quad$ In terms of climatic conditions, during the entire vegetation period, the year 2018 was most favorable for the culture ofvines in the Ștefănești area.

- $\quad$ Significant impact of climatic factors on the amount and quality of yields of this cultivars was put into evidence. However, despite the increasing influence of climate change, there are still very favorable agroecological conditions for growing 'Fetească Albă', 'Fetească Neagră' and 'Fetească Regală' cultivars in Ștefănești wine growing region.

- $\quad$ The highest sugar content of the grapes was recorded in 2020 (228,78 g/l) followed by 2019 year, and the lowest in 2017 and 2016, respectively, consequence of the variation in weather conditions in 2017 and 2016, with the lowest mean air temperature and the highest amount of precipitation during the vegetation period, the sugar content was lowest.

- $\quad$ The low content of grapes in acidity in 2019 and 2020 years is due to their higher accumulations in total sugar.

- Increasing accumulation of sugars and an excessive reduction of acidity, which affects the balance between sugar and acidity are the consequence of higher temperature during the period ripening period of the grapes. 


\section{REFERENCES}

1. Antoce Arina Oana and Cojocaru George Adrian, 2018. Characterization Of Quality Potential Of Feteasca Neagra Grapes Cultivated In Different Romanian Wine Regions. proprieties. Agriculture for Life,Life for Agriculture, Bucharest. SCIEDO DOI: 10.2478/alife-2018-0035

2. Blanke, M.M., Kunz, A. (2017). Cherry phenology as bioindicator for climate change. ActaHorticulturae, Vol.1162:17.DOI: 10.17660/ActaHortic.2017.1162.1. https://doi.org/10.17660/ActaHortic.2017.1162.

3. Busuioc, A., Dobrinescu, A., Birsan, M.V., Dumitrescu, A., Orzan, A. (2015). Spatial and temporalvariability ofclimate extremes in Romania and associated large-scale mechanisms. Internationaljournal of Climatology. https://doi.org/10.1002/joc.4054.

4.Brighenti, A. F., Rufato, L., Kretzschamar, A. A., Marcon Filho, J. L., Brighenti, L. M.,Malinovski, L. I., Da Silva, A. L. (2010): Phisical-Chemical Quality ofCabernet Sauvignon Clones in High Altitude Regionsw of Santa Catarina StateBrazil, 28th International Hortivcultural Congress, ISHS, Belgium, LisbonPortugal, vol. 2, pp. 722

5. Chitu, E., Giosanu, D., Mateescu, E. (2015). The variability of seasonal and annual extreme temperature trends ofthe latest three decades in Romania. Agriculture and Agricultural Science Procedia. Volume 6: 429437.https://doi.org/10.1016/j.aaspro.2015.08.113

6. Florea Alina, Emil chitu and Cristian Paltineanu,2020. Dynamics of phenological stages due to climate change in plum trees in southern Romania. IV Balkan Symposium on Fruit Growing. International Society for Horticultural Science.

7. Guedon, Y., Legave, J.M. (2008). Analyzing the time-course variation of apple and pear tree dates of floweringstagesin the global warming context. Ecological Modelling 219(1-2): 189-199.DOI: 10.1016/j.ecolmodel.2008.08.010

8. Miroševic, N, Jasminka Karoglan-Kontić (2008): Viticulture, Faculty of Agriculture, Zagreb

9. Mota, S. C., Talamini do Amarante, V. C, Pessoa dos Santos, H., Zanardi, Z.0 (2008): Vegetative and Yield of Cabernet Sauvignon grapevine under overhead plastic covering. Revista Brasileira de Fruticultura, 30, 148-153

10. OIV, 2009. Descriptor List for Grape Varieties and Vitis species (2nd edition). Retrieved 2016 December 20 from http://oiv.int.

11. OIV Resolution VITI 1/2008, 2008. OIV standard on minimum maturity requirements for table grapes. Retrieved 2017 December 11 from http://www.oiv.int/public/medias/369/viti-2008-1en.pdf

12. Odăgeriu Gheorghe,Zamfir Cătălin-Ioan, Crețu Claudiu, CoteaValeriu, 2012. Compositional aspects of quality wines produced in averești vine growing centre of huşi vineyard, harvest of 2011. Universitatea de Ştiințe Agricole şi Medicină Veterinară Iaşi. LucrăriŞtiinţifice - vol. 55/2012, seriaAgronomie

13. Paltineanu, C., Chitu, E., Mateescu, E. (2012).New trends for reference evapotranspiration and climatic waterdeficit. Internat. Agrophysics 26: 159-165.

14.Paltineanu, C., Chitu, E., Tanasescu, N., Apostol, G. and Pufu, M.N. (2000). Irrigation water requirements for some fruit trees specific to the Arges-Vedea river basin, Romania. Acta Hort. 537: 113-119. https://doi.org/10.17660/ActaHortic.2000.537.10

15. Waldau, T., Chmielewski, F.M. (2018). Spatial and temporal changes of spring temperature, thermal growingseason and spring phenology in Germany 1951-2015. MeteorologischeZeitschrift, (27)4: 335342.DOI 10.1127/metz/2018/092

16. Wenden, B., Mariadassou, M., Campoy, J.A., Quero-Garcia, J. and Dirlewanger, E. (2017). Statistical analysis of trends in sweet cherry flowering data across Europe. ActaHortic. 1160, 215-220.DOI: 10.17660/ActaHortic.2017.1160.31. https://doi.org/10.17660/ActaHortic.2017.1160.31

17. https: //www.madr.ro/horcultura/viticultura-vinificatie.html. 